\title{
PENGARUH STATUS GIZI DAN IMUNISASI TERHADAP PERTUMBUHAN ANAK DI DESA JETIS KARANGPUNG KALIJAMBE SRAGEN
}

\author{
The Effect Of Nutrition And Immunization Status On Children's Growth In \\ Jetiskarangpung Village, Kalijambe, Sragen
}

\author{
Sri Sayekti Heni Sunaryanti ${ }^{1)}$, Titik Anggraeni ${ }^{2)}$ \\ ${ }^{1)}$ STIKES Mamba'ul 'Ulum Surakarta \\ ${ }^{2)}$ STIKES Estu Utomo \\ (ss.heni.s29@gmail.com/ titik.anggraeni146@gmail.com)
}

\begin{abstract}
ABSTRAK
Latar Belakang: Anak merupakan bagian dari keluarga yang sangat diharapkan di mana keluarga menginginkan anak tumbuh dan berkembangan dengan normal.Pertumbuhan adalah perkembangan yang bersifat kuantitatif yang dinilai dengan ukuran berat dan panjang badan. Banyak faktor yang berpengaruh terhadap pertumbuhan anak. Masalah gizi yang kronis bisa menyebabkan terjadinya stunting. Stunting akan menganggu pertumbuhan dan perkembangan anak.

Tujuan: Penelitian ini bertujuan untuk mengetahui pengaruh status gizi dan imunisasi terhadap pertumbuhan anak.

Metode:penelitian ini kuantitatif dengan desain cross sectional. Subyek penelitian berjumlah 107 responden di desa Jetiskarangpung, Kalijambe, Sragenyang diambil dengan tehnik random sampling. Variabel dependen adalah pertumbuhan anak.Variabel independen adalah imunisasi, status gizi. Data dikumpulkan dengan menggunakan kusioner dan Kartu Menuju Sehat(KMS). Analisis data dilakukan dengan path analysis.

Hasil:ada pengaruh dari status gizi dan status imunisasi terhadap pertumbuhan anak(r square: 0,879; p: 0,000). Pengaruh status gizi secara parsial sebesar $50,5 \%(\mathrm{r} ; 0,505 ; \mathrm{t} ; 4,501 ; \mathrm{p} ; 0,000)$, status imunisasi sebesar 40,2\%(r: 0,402; $\mathrm{t}: 3,587 ; \mathrm{p:} 0,001)$.
\end{abstract}

Kesimpulan: pertumbuhan anak yang baik dipengaruhi oleh status gizi yang baik dan status imunisasi yang lengkap.

Kata kunci: status gizi, status imunisasi, pertumbuhan anak

\section{ABSTRACT}

Background: Children are part of the family that is highly expected where the family wants children to grow and develop normally. Growth is a quantitative development that is judged by the size of the body weight and length. Many factors influence the growth of children. Chronic nutritional problems can cause stunting. Stunting will disrupt children's growth and development. 
Objective: This study aims to determine the effect of nutritional status and immunization on children's growth.

Method: this research is quantitative with cross sectional design. The research subjects were 107 respondents in the village of Jetiskarangpung, Kalijambe, Sragen which were taken using random sampling techniques. The dependent variable is the growth of children. The independent variable is immunization, nutritional status. Data is collected using questionnaires and Towards Healthy Cards (KMS). Data analysis is done with path analysis.

Results: there was an effect of nutritional status and immunization status on children's growth (r square: $0.879 ; \mathrm{p}: 0,000)$. The effect of partial nutritional status is $50.5 \%$ (r; $0.505 ; \mathrm{t}$; $4.501 ; \mathrm{p} ; 0,000)$, immunization status is $40.2 \%$ (r: 0.402 ; $\mathrm{t}$ : 3.587; p: 0.001).

Conclusion: good growth of children is influenced by good nutritional status and complete immunization status.

Keywords: nutritional status, immunization status, child growth

\section{PENDAHULUAN}

Pertumbuhan merupakan perubahan yang bersifat kuantitatif atau pertambahan jumlah dan ukuran dari sel, organ, sistem organ dan individu manusia. Hal ini ditunjukan oleh seorang anak yang tidak hanya bertambah besar secara fisik, tetapi juga bertambah besar ukuran organ yang ada di dalam tubuhnya(Soetjiningsih, Gde Ganuh, 2014)

Faktor yang berpengaruh terhadap pertumbuhan dan perkembangan anak secara garis besar dibagi menjadi 2, yaitu: faktor genetik dan lingkungan. Faktor genetik mempunyai peran dan merupakan modal utama dalam mencapai tumbuh kembang yang maksimal, dengan hasil yang baik yaitu anak sehat, tumbuh menjadi individu yang berkualitas. Pertumbuhan yang baik ditandai dengan intensitas dan kecepatan pembelahan, sensitivitas jaringan terhadap rangsang, usia pubertas dan berhentinya pertumbuhan tulang. Lingkungan sangat bepengaruh terhadap pertumbuhan dan perkembangan anak. Lingkungan yang dimaksud di sini adalah lingkungan biofisikopsikososial dan spiritual yang berpengaruh terhadap anak mulai dari dalam kandungan, lahir, tumbuh kembang menjadi dewasa sampai akhir hayat. Faktor lingkungan secara garis besar dibagi menjadi 3, yaitu: pranatal, intanatal dan pascanatal.Gizi dan imunisasi merupakan bagian dari lingkungan pascanatal yang berpengaruh terhadap tumbuh kembang anak. (Soetjiningsih, Gde Ganuh, 2014).

Gangguan pertumbuhan yang terjadi di negara maju sering disebabkan karena faktor genetik, misal: sindroma down, sindrom tuner. angka kejadian di Indonesia masih rendah, seperti yang dituliskan oleh Nurwidah dkk(2015) tentang Prevalensi sindroma down di Wilayah Priangan pada tahun 2015 sebesar 0,07\% dari total populasi yang berjumlah 459 anak.

Di negara berkembang, gangguan petumbuhan terjadi karena faktor genetik dan lingkungan(Soetjiningsih, Gde Ganuh, 2014). Status gizi anak adalah keadaan makanan kesehatan yang ditentukan oleh derajat kebutuhan fisik energi dan zat- 
zat gizi yang lain yang diperoleh dari pangan dan makanan yang dampak fisiknya diukur dengan tehnik antropometri(Suharjo, 1996). Dalam profil Kabupaten Sragen tahun 2015 dituliskan balita yang berada di bawah garis merah(BGM) sebanyak 292 balita(0,8\%).

Berdasar keterangan tersebut di atas, peneliti tertarik untuk mengetahui pengaruh status kesehatan dan status imunisasi terhadap pertumbuhan anak.

\section{METODE PENELITIAN}

Desain penelitian ini adalah penelitian analitik dengan pendekatan cross sectional. pengumpulan data dilakukan pada bulan September - Desember 2017 di desa Jetiskarangpung, kalijambe, Sragen. Populasi penelitian ini adalah anak yang orang tuanya tinggal di desa Jetiskarangpung. Adapun subyek penelitian ini berjumlah 107 responden yang ditentukan dengan tehnik random sampling. Alat yang digunakan untuk mengumpulkan data adalah kuesioner dan KMS(Kartu Menuju Sehat). Analisis data menggunakan regresi linear.

\section{HASIL DAN PEMBAHASAN}

Tabel 1. Distribusi Frekuensi Karakteristik Responden berdasar Status Gizi, Status Imunisasi, Pertumbuhan Anak dan Status Kesehatan

\begin{tabular}{lcc}
\hline \multicolumn{1}{c}{ Karakteristik } & Frekuensi(f) & Persentase(\%) \\
\hline Gizi berdasar Indeks Massa Tubuh(IMT) & & \\
Normal & 93 & 47,2 \\
Tidak Normal & 14 & 6,1 \\
Total & 107 & 100 \\
Gizi berdasar data KMS & & \\
Normal & 93 & 47,2 \\
Tidak Normal & 14 & 6,1 \\
Total & 107 & 100 \\
Status Imunisasi & & \\
Lengkap & 95 & 88,8 \\
Tidak lengkap & 12 & 11,2 \\
Total & 107 & 100 \\
Pertumbuhan Anak & & \\
Normal & 93 & 47,2 \\
Tidak normal & 14 & 6,1 \\
Total & 107 & 100 \\
\hline$\quad$ Sumber data: Primer diolah & &
\end{tabular}

Tabel 1 menunjukkan distribusi frekuensi anak dengan status gizi berdasar IMT, status gizi berdasar data KMSberjumlah sama, masing-masing 93 responden(47,2\%), distribusi frekuensi anak dengan pertumbuhan normal berjumlah 93 responden $(47,2 \%)$. 
Tabel 2. Regresi Linear Pengaruh Status Gizi dan Imunisasi terhadap Pertumbuhan anak di desa Jetiskarangpung, Kalijambe, Sragen.

\begin{tabular}{|c|c|c|c|c|c|c|}
\hline \multirow{2}{*}{\multicolumn{2}{|c|}{ Model }} & \multicolumn{2}{|c|}{$\begin{array}{l}\text { Unstandardized } \\
\text { Coefficients }\end{array}$} & \multirow{2}{*}{$\begin{array}{c}\begin{array}{c}\text { Standardized } \\
\text { Coefficients }\end{array} \\
\text { Beta } \\
\end{array}$} & \multirow[b]{2}{*}{$\mathrm{t}$} & \multirow[b]{2}{*}{ Sig. } \\
\hline & & $\mathrm{B}$ & Std. Error & & & \\
\hline \multirow[t]{3}{*}{1} & (Constant) & .105 & .054 & & 1.939 & .055 \\
\hline & GIZI di KMS & .489 & .109 & .505 & 4.501 & .000 \\
\hline & STATUS IMUNISASI & .417 & .116 & .402 & 3.587 & .001 \\
\hline r squa & ; p: 0,000 & & & & & \\
\hline
\end{tabular}

Tabel 2 menunjukan bahwa secara simultan ada pengaruh dari status gizi dan status imunisasi terhadap pertumbuhan anak(r square: 0,$879 ; \mathrm{p}: 0,000)$. Hasil analisis data juga menunjukan status gizi dan status imunisasi secara parsial berpengaruh terhadap pertumbuhan anak. Pengaruh status gizi secara parsial sebesar 50,5\%(r; 0,505; t;4,501; p; 0,000), status imunisasi sebesar 40,2\%(r: 0,402; t:3,587; p: 0,001).

Status gizi merupakan kondisi kesehatan yang dipengaruhi oleh asupan dan penggunaan zat gizi. gizi atau nutrisi adalah substansi organik yang dibutuhkan organisme utnuk fungsi normal dari sistem tubuh, pertumbuhan, pemeliharaan kesehatan. Penggunaan nutrisi dalam level optimal terbukti dapat mencegah dan menanggani stres oksidatif sehingga membantu mencegah penyakit kronis. Selain itu, nutrisi yang optimal akan mendukung perkembangan sel dan jaringan sehingga akan mendorong pertumbuhan anak dengan optimal(wikipedia.org). gizi seimbang adalah susunan makanan sehari-hari yang mengandung zat gizi dalam jenis dan jumlah yang sesuai dengan kebutuhan tubuh, dengan memperhatikan prinsip keanekaragaman atau variasi makanan, aktivitas fisik, kebersihan dan berat badan ideal. Dalam penelitian ini menunjukkan bahwa status gizi berpengaruh terhadap pertumbuhan sebesar 50,5\%. Gizi berpengaruh terhadap pertumbuhan balita. Energi diperlukan oleh tubuh untuk menjalankan semua proses biologis dan kimia dalam tubuh. Energi diperoleh dari proses metabolisme dari semua zat gizi yang dikonsumsi dan masuk ke dalam tubuh, khususnya protein akan membangun serta memelihara sel dan jaringan dalam tubuh(Almatsier S, 2006)

Dalam penelitian sebelumnya, yang dilakukan oleh Solihin RDM, dkk(2013) menyatakan bahwa status gizi balita berpengaruh terhadap perkembangan motorik halus(r: 0,272; p: 0,020). Penelitian ini saling melengkapi dan bisa diketahui bahwa status gizi berpengaruh terhadap pertumbuhan dan perkembangan anak, khususnya motorik halus.

Imunisasi adalah proses untuk membuat seseorang kebal terhadap penyakit yang diberikan dengan memberikan vaksin yang merangsang sistem kekebalan tubuh agar kebal terhadap penyakit tersebut. Imunisasi sebagai satu upaya preventif untuk mencegah penyakit melalui pemberian kekebalan tubuh yang dilaksanakan terus menerus, menyeluruh dan dilaksanakan sesuai standar sehingga mampu memberikan perlindungan kesehatan dan memutuskan mata rantai penularan(KMKRI, 2004). 
Penelitian yang penulis lakukan ini menunjukan bahwa status imunisasi berpengaruh terhadap pertumbuhan sebesar 40,2\% (r: 0,402; t:3,587; p: 0,001). Salah satu penelitian yang dilakukan di Kabupaten Lebak, tahun 2008 tentang imunisasi yang dilakukan sebelumnya adalah hubungan imunisasi denngan kejadian campak. Penelitian tersebut menunjukan bahwa imunisasi memiliki hubungan yang bermakna dengan kejadian campak $(\mathrm{P}=0,000, \mathrm{OR}=101,750)$, yang menunjukkan bahwa dengan diberikan imunisasi campak, anak akan terbebas dari penyakit campak, ini berarti anak tetap sehat bisa tumbuh dan berkembang dengan sempurna(Khotimah H, 2015). Dua penelitian ini sesuai dengan teori yang dituliskan oleh Soetjiningsih dan Gde Ganuh(2014) yang menyatakan bahwa perawatan kesehatan berpengaruh terhadap pertumbuhan dan perkembangan anak. Yang dimaksud perawatan kesehatan di sini mencakup pemeriksaan kesehatan, imunisasi, skrining dan deteksi dini gangguan tumbuh kembang, stimulasi dini termasuk pemantauan pertumbuhan dengan menimbang anak rutin setiap bulan di posyandu.

\section{SIMPULAN DAN SARAN}

\section{Simpulan}

Status gizi yang baik dan status imunisasi lengkap akan mendukung pertumbuhan anak menjadi lebih baik(r square: 0,879; p: 0,000). Status gizi secara parsial berpengaruh terhadap pertumbuhan anak sebesar 50,5\%(r; 0,505; t;4,501; p; 0,000), dan pengaruh status imunisasi sebesar 40,2\%(r: 0,402; t:3,587; p: 0,001).

\section{Saran}

Dari hasil penelitian ini diharapkan bisa menjadi motivasi bagi orang tua untuk memberikan imunisasi lengkap dan memberikan gizi yang cukup agar anak bisa tumbuh dan berkembang secara optimal.

\section{DAFTAR PUSTAKA}

Almatsier, 2006, Prinsip Dasar Ilmu Gizi, Gramedia, Jakarta.

Keputusan Menteri kesehatan Republik Indonesia Nomor 1059/MENKES/SK/IX/2014 tentang Pedoman Penyelenggaraan Imunisasi. www.depkes.go.id. Diakses tanggal 2 Febuari 2019.

Khotimah, H,. 2015., Hubungan Antara Usia, Status Gizi dan Status Imunisasi dengan kejadian Campak Balita. www.ejournal.latansa.mashiro.ac.id. Diakses tanggal 2 Febuari 2019.

Nurwahidah S,. Suwondo, W,. dan Sasmita IS. 2015. www.jurnal.unpad.ac.id. Diakses tanggal 2 Febuari 2019

Solihin RDM,.Anwar F., Sukandar D., 2013. Penelitian Gizi dan Makanan, http://www.neliti.com. Diakses 2 Febuari 2019

Soetjiningsih, Gde Ganuh, 2014, Tumbuh Kembang Anak Edisi 2, EGC, Jakarta.

Suharjo, 1996, Gizi dan Pangan, Kanisius, Yogyakarta 